\title{
Faculty as border crossers: A study of Fulbright faculty
}

Pamela L. Eddy

College of William and Mary, pamela.eddy@wm.edu

Follow this and additional works at: https://scholarworks.wm.edu/educationbookchapters

Part of the International and Comparative Education Commons

\section{Recommended Citation}

Eddy, Pamela L., "Faculty as border crossers: A study of Fulbright faculty" (2014). School of Education Book Chapters. 30.

https://scholarworks.wm.edu/educationbookchapters/30

This Book Chapter is brought to you for free and open access by the School of Education at W\&M ScholarWorks. It has been accepted for inclusion in School of Education Book Chapters by an authorized administrator of W\&M ScholarWorks. For more information, please contact scholarworks@wm.edu. 
As adult learners, faculty members approach new experiences based on events of the past, but this underlying framework of understanding is challenged when they work abroad for an extended period of time.

\title{
Faculty as Border Crossers: A Study of Fulbright Faculty
}

\author{
Pamela L. Eddy
}

Internationalization efforts on college campuses are on the increase. An expectation and goal of a university education is to develop global competencies of college graduates (Knight, 2009). Involvement in international endeavors also helps to heighten institutional prestige through higher global rankings (Hazelkorn, 2011), which are based in part on faculty research productivity and international reputation. Today's faculty lead study abroad classes, conduct internationally based research, and incorporate international perspectives in their teaching. Fulbright awards provide one venue in which faculty are able to immerse themselves into an international context, develop their teaching and research, and create and maintain connections for partnerships. The research presented in this chapter was conducted in Ireland with both U.S. and Irish Fulbright scholars. A qualitative study using a phenomenology design included 10 scholars, four were Irish scholars who had Fulbright awards in the United States and six were U.S. scholars with Fulbright awards in Ireland. The questions guiding the study sought to understand faculty learning in an international context.

In 2003, Ireland's higher education policy was reviewed by the Education Committee of the Organisation for Economic Co-operation and Development (OECD), of which Ireland is one of the 20 member countries (OECD, 2006). One of the outcomes of this report was a need to increase recruitment of international students. Not only is there a financial benefit to recruiting a diverse student body, the creation of a diverse student culture enhances learning for all students and helps fulfill the civic and educational mission of universities (Hurtado, 2007). Many colleges and

The author gratefully acknowledges funding from the Irish Fulbright Program in support of this project. 
universities in the United States are also focused on including global competency as a goal for student learning outcomes upon graduation (Romano, 2002). Study abroad programs have long been a staple of the college experience for students, but the need to compete in a global economy presses institutions to think more intentionally about how to internationalize curriculum, educate students to become global citizens, and engage with institutions around the world in joint degree programs and cooperative research. A linchpin to these efforts is college faculty members.

Altbach and Lewis (1996) reported findings from the 1992 Carnegie Foundation for the Advancement of Teaching's International Survey and noted that only one in three U.S. faculty had taken at least one trip abroad for study or research. Recently, a team of researchers conducted a survey to determine what changes have occurred for U.S. faculty in the past decade. Finkelstein, Walker, and Chen (2013) found that faculty members are still insular in their scholarship and in internationalizing the curriculum. The researchers note that adult years spent abroad were the most pervasive and powerful predictor of faculty internationalizing their curriculum, working with and publishing in collaboration with international colleagues, having research that is international in scope, and publishing in foreign countries. Pointedly, the American Council on Education's (2012) Mapping Internationalization on U.S. Campuses survey, conducted in 2011, indicated decreases in faculty development support to assist internationalization efforts and corresponding decreases in internationally focused curriculum. Calls for creating comprehensive internationalization still show mixed success (Peterson \& Helms, 2013).

Though insufficient, there is still support for faculty efforts to create comprehensive internationalization. For example, Beloit College created a program to allow its faculty opportunities abroad to help foster faculty learning that could be translated into curricular changes to improve student global competencies (Brewer, 2010). Efforts at the College of William and Mary also illustrate changes underway to help with internationalization efforts (Eddy, Barber, Holly, Brush, \& Bohan, 2013). For faculty members without these types of institutional supports, however, efforts are often individually driven.

U.S. Senator J. William Fulbright introduced a bill that was established as a law in 1946 creating the Fulbright Program. The intention of the program is to help build bridges between countries that create an enhanced understanding of and compassion for world affairs and provide the basis for peaceful coexistence. In Ireland, the Fulbright Program was started in 1957 to provide scholarships to Irish citizens to lecture, research, or study in the United States and for U.S. citizens to lecture, research, or study in Ireland (Fulbright, 2013). The Fulbright Program provides a forum ripe for investigating the faculty experience in an international setting and determining how faculty perceive the experience affects or will affect their teaching and research upon their return to their home country. 


\section{Literature Review}

The increased demand for college graduates to possess intercultural skills and competencies (American Council on Education [ACE], 2012) requires internationalization on campus that includes these same skills in faculty members. One way that "faculty gain international perspectives is through teaching and research opportunities abroad and by building relationships with peers in other countries" (ACE, 2012, p. 14). Yet only $8 \%$ of institutional promotion and tenure guidelines specifically recognize this type of international work when considering tenure or promotion. Moreover, funding to support faculty travel abroad has declined nationally (ACE, 2012) and fiscal exigency in Ireland has reduced university funding (Higher Education Authority, 2013). Thus, while there is recognition of the need to increase internationalization efforts on campus, there is a lack of structural support and recognition for the efforts of faculty in their international work (Eddy et al., 2013). As well, a gap exists in the literature in understanding how faculty who do pursue international experiences incorporate their learning experiences into internationalization efforts on their home campuses.

To understand better the process of learning for the faculty involved in international experiences, it is important to look at adult learning theory. When faculty members work abroad, they incorporate their new experiences into their underlying schemas and ways of knowing. Andragogy (Knowles, 1970) describes the ways in which adults learn. The five basic features of andragogy include that adults: (a) have rich life experiences to link to new learning, (b) employ self-directed learning, (c) are goal oriented and practical, (d) are intrinsically motivated, and (e) learn based on their life role needs. As adult learners, faculty and campus leaders continuously sift through new information and experiences to determine how it meshes with what is known, what is new, and what should be incorporated for future understanding. Thus, while working abroad, faculty members understand their new encounters through a filter of past experiences.

According to Kegan and Lahey (2009), there are three plateaus for adult mental development: the socialized mind, the self-authoring mind, and the self-transforming mind. The attributes of the socialized phase of development focus on being a team player, aligning with the group, and seeking direction. The self-authoring phase instead finds individuals driven by their own agendas, problem solving, and becoming independent. Finally, the selftransforming mind phase finds individuals valuing multiple perspectives, modifying plans based on feedback, and relying on interdependency with others. A feature of this model of development is the lengthening of time between development phases and time at each plateau phase; ultimately, fewer and fewer people achieve the higher levels of development.

The conceptual model for this study utilized adult learning theory (Knowles, 1980; Merriam \& Brockett, 2007). Kegan and Lahey's (2009) plateaus for adult learning helped inform the location used by faculty 
members to "hook" their new learning to existing approaches to learning. Literature on the changing nature of faculty work (Gappa, Austin, \& Trice, 2007) and the support of international faculty development (ACE, 2012) also informed this research as the demands on faculty time influence the type and extent of learning that occurs for faculty members.

\section{Methods}

This research used qualitative methods to investigate a particular phenomenon (Creswell, 2007), which in this research was the teaching and learning experiences of faculty members participating in an exchange program. The research questions underpinning this study were: How do faculty members describe their own learning in an international context? How do faculty members describe teaching and learning in their new context? How do faculty members anticipate their international experience will change their own teaching?

A qualitative method of data collection was used for this research, hermeneutic phenomenology (Van Manen, 1990), as this allowed for delving into the topic using the participants' voices and perspectives (Creswell, 2007). Phenomenology provided a focus on the experiences of our participants as faculty members teaching in a new context, whereas using hermeneutics allowed for interpretation of the phenomena versus merely describing it. The goal was to understand how faculty members incorporated the experience of teaching and researching abroad into their own learning. The focus in particular centered on the components of the international experience that altered individual thinking about teaching and learning and what it means for creating an environment that fosters intercultural competency for students.

Participants were purposefully selected. Polkinghorne (1989) argues that between five and 25 participants should be included when conducting a phenomenology. A total of 30 U.S. scholars were awarded Fulbright scholarships for an exchange in Ireland in the 2008-2009 academic year. Of this total, 12 were engaged in teaching responsibilities. All were contacted for participation in this research and six participated in the study. A total of nine Irish scholars who taught in another country within the past five years were also contacted for inclusion in this research and four ultimately participated. A semistructured interview protocol allowed for the investigation of the phenomenon of the learning experience. Interviews occurred face-to-face in Ireland in spring 2009.

The participants represented a narrow range of ethnic groups (all White) and were predominately men (only one woman was included in the study). Quotes appearing in this chapter are coded to represent gender (women = F; men = M) and country of origin (US = United States; IRE = Ireland). The demographic portrait of the participants is common in Ireland, with the majority of the population composed of Whites. The 
gender participation in Fulbright Scholar programs in the years under review was predominately men (seven of the nine Irish scholars and 10 of the 12 U.S. scholars). Participants worked in a variety of Irish and American universities, ranging from private liberal arts colleges to public research universities. Each was embedded in a smaller department and most of their reflections dealt with work at the departmental level versus the university. The Irish scholars and the U.S. scholars ranged in their time in their host country, with visits ranging from a full year to others that were six months or a semester in length.

A limitation of this research is the focus on two countries for the exchanges, Ireland and the United States. Cultural context of other countries may have different types of learning occurring for the faculty members. In particular, when language and customs are markedly different, other levels of cognitive dissonance might occur. As well, my own identity construction and participation in the Fulbright Scholar program may create bias. To guard against this bias, I used member checking and a peer reviewer. Geertz (1993) argued that researchers and participants are equally involved in creating understanding of the findings. Thus, my positionality as cultural insider not only provided an ability to establish rapport with the participants (Ganga \& Scott, 2006) but also meant I had to guard against making assumptions about participants' meaning. Specifically, I was a U.S. scholar doing research in Ireland, though I did not have any teaching responsibilities to allow for comparisons of the classroom examples participants related. Because I brought emic perspectives to the research, I was particularly careful to bracket my assumptions during data analysis (Creswell, 2007).

\section{Findings and Discussion}

Three findings emerged from the data. First, disequilibrium provided a launch point for learning. When pushed out of their comfort zones, faculty members were open to new learning. Second, faculty experienced a move from expert/insider to novice/outsider as a result of the new international context. Old and engrained understandings were tested in the new environment. Finally, an integration of personal and professional reflection occurred that resulted in learning crossing the boundaries of work and family, and home and host country. Ultimately, transformational learning occurred due to critical reflection by faculty members of their experiences. Implications for practice include bridging the faculty experience abroad with opportunities to enhance student learning, providing faculty development opportunities in advance of faculty leaving the country to allow for enhanced learning, and building theory regarding the integration of learning for faculty members.

For the U.S. scholars, Irish ancestry or love of Irish literature and music were motivators in seeking out Ireland as the site for their Fulbright. When asked Why Ireland?, the responses included: "My family background-this 
is where we're from and I wanted to come back and stay here an extended amount of time" (F-US); "I'm an Irishman!" (M-US); "I toured Ireland and met people who had read all my books_-and I was famous! ... I found a network I accidentally had fallen into" (M-US). For the Irish scholars, studying in the United States provided an opportunity to work with high-level researchers and to connect their work using an interdisciplinary perspective. One of the Irish scholars commented, "I find that in my work [in Ireland], I'm asked, What are you? Are you this or that? Where in America, people were very interested in this kind of work and openness. That was very refreshing" (M-IRE). The Irish scholars had connections to U.S. researchers based on their disciplinary associations and built on this social network to secure their institutional affiliations in the United States. Despite this sense of belonging and fit, challenges emerged for the faculty working abroad.

Disequilibrium. Faculty members faced a number of incidents in which they were pushed out of their typical patterns of understanding. One faculty member commented, "I haven't been alone probably ever in my life, ever [laughs]. I went from sharing rooms with brothers to roommates in college to marriage. Being alone and independent was a new experience. I think I've grown in ways I probably don't deserve" (M-US). This faculty member recognized how the disequilibrium created as result of his moving halfway around the world provided a context for him to grow and develop. This type of self-authorship was not evident to this faculty before. Because many of the Fulbright scholars traveled with family members, the learning they experienced bridged the professional and the personal and involved the assimilation of family members into the new locale as well.

Likewise, other faculty described how they initially felt isolated, as one physics faculty noted, "It turned out professionally that it was hard to get started" (M-US). Getting used to the shared values of the educational structure in the host country was an adjustment. One U.S. faculty commented, "I was really surprised how international students were. I guess I wasn't expecting that. I had this image I would come in and I would be teaching Irish students ... and it's been really interesting to see these international students coming in brand new to Ireland too and blind to the culture" (F-US).

An American faculty noted that the course structure was different and contained more of a hands-on component. Another found that the fact that most students didn't attend lectures and only showed up for the exams to be disconcerting. Whereas another offered, "The system is set up [in my department] at the University College-Dublin so that it's impossible to teach the way Americans consider teaching a college class" (M-US). He added, "I was not given any orientation-they took for granted that I was immediately oriented to a system that was absolutely alien." Irish faculty members also referenced differences they experienced in the classroom.

According to one Irish faculty, American students sought more structure for classroom teaching and desired their hard work to equate to a good 
grade. The Irish faculty noted, "The students would think 'I worked hard enough so I deserve it [a good grade].' I found that difficult to deal with." In this case, the disequilibrium was based on differences in classroom expectations of faculty and students. This same faculty noted, "My role as a professor here is to give information... whether they get it or not doesn't really affect me and does not matter."

One Irish faculty described his culture shock in the classroom. He added, "I was really not prepared for it to be quite honest on a whole range." His placement at an elite U.S. university exposed him to students who were "the brightest students in their city," and as a result in classroom participation the students felt "that every word that they say they think has to be pure gold. So there is absolutely no free speech for random ideas is another thing." The type of student participation and expectations in class created a different teaching context for the exchange faculty. The different expectations of faculty work were a source of initial disequilibrium and ultimate learning. Participants clearly identified experiences that located them in the self-authoring developmental stage (Kegan \& Lahey, 2009). They were selfdirected and innovative, but also identified traits in the transforming stage of development. The faculty members noted how they changed plans based on student and colleague feedback and how they now understood more fully multiple perspectives of teaching and learning and their faculty role.

Expert to Novice. As adult learners, the faculty in this study came to their new experiences with a vast range of backgrounds and expertise. Yet, the move across the ocean to work in another institution left them ungrounded by their sense of disequilibrium and by the fact that they were now novices as they approached their new positions. One U.S. faculty recounted his first weeks at his Irish college, "I was really nervous those first few weeks because they started to assign me modules [to teach] and I didn't want to do that. Partly because I hadn't taught that module before, even though it was related to the research I do, and teaching a new module for me is very intensive" (M-US). By the spring term, this faculty member noted, "I felt like I had more expertise." Moving back to a novice position resulted in learning opportunities for the faculty members in their host countries, with all the faculty noting how they had grown over the course of their stay. Faculty began entering the self-transforming stage (Kegan \& Lahey, 2009) as they gained multiple perspectives on their teaching.

The difference in the teaching structure also meant that final exams in Ireland were prepared three months ahead of time and reviewed by external examiners. This procedure was foreign to the U.S. faculty. As well, the courses were shorter and students often did not attend lectures. One U.S. faculty noted, "One thing that was very difficult for me was to try to compress my normal teaching into a shorter timeframe. I had to do a lot of thinking about what to present to the students" (F-US). This self-reflection resulted in questioning of the assumptions about how to format the time 
with students and to trust that the students were engaged with the reading materials outside of class to provide discussion of advanced topics when in class together.

For an American film instructor, the adjustment was difficult given the lack of space and format to show films for discussion. He noted, "In America, I'd show 20-25 films per class and I'm teaching two classes, so I tried to bring 80 films. They didn't have a film room, so they bought a DVD player and put us in a room with a big screen." The difference in physical space and expectations about technology pressed faculty to approach their teaching differently. An American music faculty related how for each of his classes he had to cart equipment to the lecture classroom.

The extreme of a move from expert to novice occurred for a faculty member charged with teaching a lecture on the civil war-a content area far removed from his discipline. He reflected, "It ruined my whole semester. Thinking about it. It was the low point of my existence" (M-US).

A shift for one of the Irish faculty involved the range of experience of students in his U.S. class and the level of engagement. He commented on his lecture preparation offering, "I guess what was interesting was how useless this was in several of the seminars, because I would put up the first slide and the discussion would start and I'd realize that I had 30-40 slides and I never got past one." Heightened levels of class participation resulted in a shift in his teaching style relative to what worked for him in Ireland versus what he faced in a U.S. classroom. When asked about his experiences teaching in the United States, another Irish faculty kept commenting, "So, this was completely new," and offered how some of the strategies he learned during his U.S. Fulbright he brought back to his teaching in Ireland.

One of the Irish faculty attended conferences in Montana and Oregon and observed how these experiences challenged what he understood as the norm for U.S. higher education. He commented on the poverty he saw in some of the rural locales, but how the conference participants were eager to learn about Irish history and the peace movement in Northern Ireland. This faculty member worked to reconcile this dissonance in his experiences. Again, the growth for the faculty in general occurred due to their firsthand experience in understanding the different perspectives of teaching, student approaches to learning, and assumptions of classroom practices.

Transformation via Integration. The faculty in this study all noted how their experiences had transformed their way of thinking, highlighting the third phase of Kegan and Lahey's (2009) stage model of selftransformation. But, this transformation was not based only on their professional work during their Fulbright. As noted above, the purpose of the Fulbright is to understand more about another culture. Faculty members integrated the learning they were doing through their work and lived experiences in the community, reflecting on previously held assumptions that ultimately resulted in exhibiting attributes of the self-transforming mind. For the bulk of the faculty, their Fulbright was the longest period of their 
adult life in which they lived in a different culture. Though some had experienced study abroad, this new experience as an adult was different. As one U.S. faculty commented, "And it turned out, for me trying something different on sabbatical, having a different experience from what I was used to, going out of my comfort zone, intrigued me, even though it makes more work." Exposure to different teaching strategies, new university processes, and being in a different environment required the faculty to question underlying assumptions held by their previous experiences and to rely on others in the host institution for information and feedback. Faculty participants were able to articulate specific takeaways they learned in their experience. As one faculty reflected, "I've been able to compare and contrast with what I'm used to" (M-US).

As one U.S. Fulbrighter noted, "I found, just by asking someone their name, and when you see them again, going to a place regularly, that person remembers you and suddenly it feels like, 'Oh I have a friend here.' Back home there are faces I see every day, in a coffee shop or something, and I've never even thought about asking them what their name was." Also, having an international experience highlighted for faculty that the problems faced in their discipline are not unique to their home country, but truly are global in nature.

The Fulbright provided the faculty with an opportunity to think about their home country differently, too. One U.S. faculty noted how he appreciated the United States differently as a result of the experience, but also how it made him realize what he formerly took for granted as a professor regarding the autonomy in the U.S. system of higher education. An Irish faculty reflected that in America his focus on interdisciplinary work was valued, whereas in Ireland he often faced questions that attempted to locate his work in one discipline or another. This faculty found he faced a kind of "status shock" when returning to Ireland. He expanded on how this status shock differed from culture shock: "You know from the openness of America-to giving a number of keynote address to coming back where you are just a regular PhD person." He found the transformational experience he had in the United States difficult to maintain upon his return home due to teaching structures in place and disciplinary norms. He maintained ties with his host U.S. institution that allowed him an outlet that valued the work he was doing.

The Irish faculty had all been in other countries prior to their Fulbright given the proximity of Ireland to the European continent. Thus, their views on the international experience were grounded most often in the local university and classroom culture versus in the experience of visiting or living somewhere outside their home country. Yet, the culture of the United States differed enough from their European experience that their day-to-day living still had some influence on the creation of a more complex understanding of differences. 


\section{Conclusion}

For the Fulbright faculty in this study, crossing borders provided them with an opportunity to question their assumptions about teaching, to explore a culture different than their own, and to grow both personally and professionally in ways they had not anticipated. The disequilibrium of time spent abroad and the shift from expert to novice provided a context ripe for learning. Although faculty had responsibilities in their temporary positions, they had freedom to explore new topics and areas given their release from their home institution responsibilities. The time away provided a space for reflection and put in stark relief assumptions they formerly held. These faculty members represent the small percentage that Kegan and Lahey (2009) found in their last phase of adult learning — self-transforming. Yet, even though the faculty participants observed how they had changed, it is important to note that transformation occurred along a continuum depending on life stage, experiences, and level of reflection.

This research holds a number of implications for practice. First, the experiences of the faculty participants underscore what Finkelstein et al. (2013) concluded, namely, how critical it is to get faculty to visit other countries. This conclusion is particularly salient for U.S. faculty who travel abroad less frequently compared to their European counterparts who may enter another country in sometimes as little as one or two hours of travel. But, gains were also evident for the Irish faculty as so much of the borrowing of higher education system models around the world builds on what is done in the United States. Second, the faculty all noted how their learning and questioning of previous assumptions would transform their own teaching practices upon return to their home institutions. Thus, students at the home institutions will benefit from the faculty learning as these teachers transform and internationalize their own teaching. A direct influence of the Fulbright faculty on students at their host institution also occurred. As one Irish faculty member related, "I continue to write reference letters for [the students at my host institution]." Finally, the transformational learning that occurred for the faculty members resulted from the ways they integrated what they were learning across professional and personal domains. Much as Barber (2012) advocates for student integration of learning, the same need for integration holds true for faculty learning too. Faculty learning how to navigate in a foreign land, living among different communities, and working in new contexts all stretched former understandings. Having a space in which to reflect on their new learning and sharing it with others helped reify the transformation. Having expectations challenged helped in achieving new learning and perspectives.

Not all universities or colleges provide the opportunity for sabbatical leaves and the limited number of Fulbright awards results in only a select few having an opportunity to partake in these types of exchanges. However, faculty members and institutions can support this type of transformational 
learning in a number of ways. Brewer (2010) showcases how a small liberal arts campus helped support faculty learning with short international trips. The opportunity to host visiting scholars on campus provides another chance for learning about different systems and approaches. Finally, technology opens the world in very different ways so that exchanges can occur virtually. What this research concludes is that faculty learning is enhanced by a change in context that disrupts typical patterns of behaviors. Through instances of disequilibrium and vulnerability of moving from expert to novice, transformational learning is possible.

\section{References}

Altbach, P. G., \& Lewis, L. S. (1996). The academic profession in international perspective. In P. G. Altbach (Ed.), The international academic profession portraits of fourteen countries (pp. 3-48). Princeton, NJ: Carnegie Foundation for the Advancement of Teaching.

American Council on Education (ACE). (2012). Mapping internationalization on U.S. campuses: 2012 edition. Washington, DC: Author.

Barber, J. P. (2012). Integration of learning: A grounded theory analysis of college students' learning. American Educational Research Journal, 49(3), 590-617. doi:10.3102/0002831212437854

Brewer, E. (2010). Leveraging partnerships to internationalize the liberal arts college: Campus internationalization and the faculty. In P. L. Eddy (Ed.), New Directions for Higher Education: No. 150. International collaborations: Opportunities, strategies, challenges (pp. 83-96). San Francisco, CA: Jossey-Bass.

Creswell, J. W. (2007). Qualitative inquiry \& research design: Choosing among five approaches (2nd ed.). Thousand Oaks, CA: Sage.

Eddy, P. L., Barber, J. P., Holly, N., Brush, K., \& Bohan, L. (2013). Internationalizing a campus: Bridging colonial roots to modern times. Change Magazine, 45(6), 43-50.

Finkelstein, M. J., Walker, E., \& Chen, R. (2013). The American faculty in an age of globalization: Predictors of internationalization of research content and professional networks. Higher Education, 66, 325-340. doi:10.1007/s10734-012-9607-3

Fulbright. (2013). Fulbright program in Ireland. Retrieved from http://www.fulbright.ie /fulbright-program-in-ireland

Ganga, D., \& Scott, S. (2006). Cultural "insiders" and the issue of positionality in qualitative migration research: Moving "across" and moving "along" researcher-participant divides. Forum Qualitative Sozialforschung/Forum: Qualitative Social Research, 7(3). Retrieved from http://www.qualitative-research.net/index.php/fqs/article/view/134

Gappa, J. M., Austin, A. E., \& Trice, A. G. (2007). Rethinking faculty work: Higher education's strategic imperative. San Francisco, CA: Jossey-Bass.

Geertz, C. (1993). The interpretation of cultures. London, England: Fontana Press.

Hazelkorn, E. (2011). Rankings and the reshaping of higher education: The battle for worldclass excellence. Hampshire, England: Palgrave Macmillan.

Higher Education Authority. (2013). Annual Report: 2011. Dublin, Ireland: Author. Retrieved from http://www.hea.ie/sites/default/files/hea_annual_reports_and_accounts 2011.pdf

Hurtado, S. (2007). Linking diversity with the educational and civic missions of higher education. Review of Higher Education, 30(2), 185-196.

Kegan, R., \& Lahey, L. L. (2009). Immunity to change: How to overcome it and unlock the potential in yourself and your organization. Boston, MA: Harvard Business Press. 
Knight, J. (2009). New developments and unintended consequences: Whither thou goest, internationalization? In R. Bhandari \& S. Laughlin (Eds.), Higher education on the move: New developments in global mobility (pp. 113-124). New York, NY: The Institute of International Education.

Knowles, M. S. (1970). The modern practice of adult education. Andragogy versus pedagogy. Englewood Cliffs, NJ: Prentice-Hall.

Knowles, M. S. (1980). The modern practice of adult education: From pedagogy to andragogy (Revised and Updated). Englewood Cliffs, NJ: Prentice-Hall.

Merriam, S. B., \& Brockett, R. G. (2007). The profession and practice of adult education: An introduction. San Francisco, CA: Jossey-Bass.

Organisation for Economic Co-operation and Development (OECD). (2006). Reviews of national policies for education: Higher education in Ireland. Paris, France: Author.

Peterson, P. M., \& Helms, R. M. (2013). Internationalization revisited. Change Magazine, 45(2), 28-34.

Polkinghorne, D. E. (1989). Phenomenological research methods. In R. S. Valle \& S. Halling (Eds.), Existential-phenomenological perspectives in psychology: Exploring the breadth of human experience (pp. 41-60). New York, NY: Plenum Press.

Romano, R. M. (2002). Internationalizing the community college. Washington, DC: Community College Press.

Van Manen, M. (1990). Researching lived experience: Human science for an action sensitive pedagogy. New York: State University of New York Press.

PAMELA L. EDDY is a professor of higher education at the College of William and Mary. 